\title{
Do Brokers' Recommendation Changes Generate Brokerage? Evidence from a Central Limit Order Market
}

\author{
Rob BROWN ${ }^{\mathrm{a}}$, Howard W.H. CHAN ${ }^{\mathrm{a} *}$, Robert W. FAFF ${ }^{\mathrm{b}}$, Yew Kee HO$^{\mathrm{c}}$ \\ JEL classification: G24
}

Keywords: Recommendation changes; Brokerage; Central limit order market; Volume traded

${ }^{a}$ Department of Finance, University of Melbourne, AUSTRALIA

${ }^{\mathrm{b}}$ UQ Business School, University of Queensland, AUSTRALIA

${ }^{c}$ Department of Accounting, National University of Singapore, SINGAPORE

* Corresponding author.

Tel: 6138344 7166; Fax: 61383446914

e-mail address: chanhw@unimelb.edu.au

Acknowledgements: We thank the Australian Centre for Financial Studies for their generous financial support. We are grateful to East Coles, IRESS and SIRCA for assistance with data. The first, second and third authors are grateful to, respectively, the University of Manchester, Monash University and the University of Amsterdam for support during sabbatical leaves. We are grateful to William Tang for expert computing assistance and to Jennifer Juergens for helpful discussions. We also thank staff at Acorn Capital for feedback.

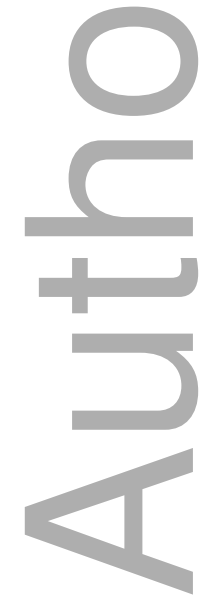

This is the author manuscript accepted for publication and has undergone full peer review but has not been through the copyediting, typesetting, pagination and proofreading process, which may lead to differences between this version and the Version of Record. Please cite this article as doi: 10.1111/acfi.12255

This article is protected by copyright. All rights reserved 
Received Date : 30-Aug-2016

Revised Date : 08-Oct-2016

Accepted Date : 17-Nov-2016

Article type : Original Article

(19)

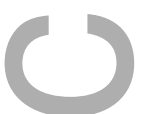

Do Brokers' Recommendation Changes Generate Brokerage? Evidence from a Central Limit Order Market

\section{JEL classification: $\mathrm{G} 24$}

Keywords: Recommendation changes; Brokerage; Central limit order market; Volume traded

${ }^{a}$ Department of Finance, University of Melbourne, Australia

${ }^{\mathrm{b}}$ UQ Business School, University of Queensland, Australia

${ }^{c}$ Department of Accounting, National University of Singapore, Singapore

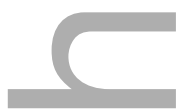

Acknowledgements: We thank the Australian Centre for Financial Studies for their generous financial support. We are grateful to East Coles, IRESS and SIRCA for assistance with data. The first, second and third authors are grateful to, respectively, the University of Manchester, Monash University and the University of Amsterdam for support during sabbatical leaves. We are grateful to William Tang for expert computing assistance and to Jennifer Juergens for helpful discussions. We also thank staff at Acorn Capital for feedback. 


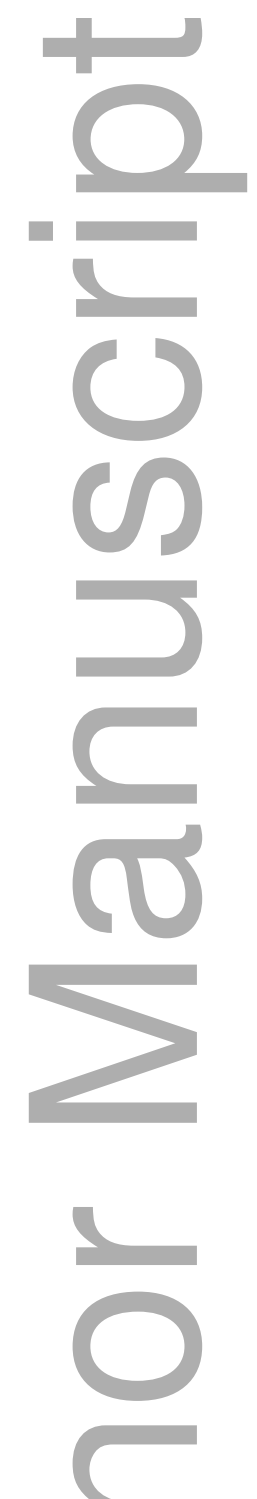

DO BROKERS' RECOMMENDATION CHANGES GENERATE BROKERAGE? EVIDENCE FROM A CENTRAL LIMIT ORDER MARKET

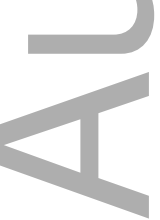

ABSTRACT

This article is protected by copyright. All rights reserved 
We examine the short-term response to recommendation changes on the ASX, a central limit order market. In both central limit order markets and dealer-driven markets, clients may reward the recommending broker with increased trade volumes. But a central limit order market does not have mandatory market-makers and hence provides greater opportunity to free ride. We find evidence supporting the hypothesis that recommending brokers are rewarded with higher trade volumes and brokerage commission. Consistent with the tipping hypothesis, these rewards are concentrated in the period shortly before the release. There is no evidence of free riding.

\section{Introduction}

Juergens and Lindsey (2009) (hereafter, J\&L) use a sample of NASDAQ firms to investigate short-term volume responses to the release of analyst recommendation changes for a dealerdriven system with market makers. J\&L find that recommending brokers who are also market makers are rewarded with higher trading volumes. They conclude that recommending full-service brokers are rewarded by traders with higher volumes as a form of compensation for the costs of undertaking research. However, the generalizability of their findings to other market trading systems is a significant empirical question because predominantly dealerdriven systems, such as that used on NASDAQ, are not necessarily representative of stock markets generally. Indeed, Jain (2003) documents that of the 51 stock markets he investigated, 26 used pure or relatively pure central limit order book systems. These markets included Australia, China, Germany (for stocks included in the DAX index), New Zealand, Paris, Singapore, Sweden and Taiwan. These 26 markets represented $28 \%$ of the market capitalization of the 51 markets, as against $23 \%$ for the 10 markets in the 'dealer emphasis' category, which includes NASDAQ. The hybrid category, which covers markets that have significant elements of dealer emphasis and a central limit order book, contained 15 markets, representing approximately $50 \%$ of market capitalization. In similar vein, Clayton et al. (2006) classified exchanges into two categories: 'market maker systems' and 'market participant systems'. The latter category includes order-driven systems. Of the 143 stock markets surveyed, 85 used market maker systems and 58 used market participant systems. The existing trading systems form a spectrum ranging from the extreme of a pure dealerdriven trading system (or, market-marker system) at one end to a pure market participant trading system at the other. Most trading systems will fall between the two extremes. Accordingly, the primary goal of our paper is to investigate the generalizability of J\&L's 
conclusions which leans towards a pure dealer-driven trading system as against the Australian pure market participant trading system.

Why should the type of share trading system matter? We argue that the trading system can have an important influence on the volume response to a recommendation. Consider a pure dealer-driven market with designated market makers. A designated market maker has a specific role recognized by the exchange authorities, whereas in a pure order-driven market all brokers are in principle equal. None has an official role that differs from other brokers. In particular, in dealer-driven markets, only designated market makers display bid and ask prices and only they are required to trade in the designated stock (both buying and selling) if called upon to do so by another broker. Hence, designated market-makers in a particular stock usually have a higher profile in relation to a given stock than do other brokers. If a fullservice broker who is also a market maker releases a recommendation on a designated stock, and that recommendation results in executed trades that would not otherwise have been done, then the total volume of business for this given stock by the subset of brokers who are market makers must increase. Consequently, the major issue is not whether trades done by the market maker providing the recommendation increase, but rather whether they increase disproportionately compared to trades executed by other market makers in the stock. In contrast, in an order-driven system with a central limit order book, all brokers are able to display bid and ask prices (and quantities). In a sense, in such a system, all brokers are able to act as market makers. ${ }^{1}$

This setting gives rise to several related questions relevant to our paper. What benefits (if any) are gained by the broker providing the recommendation? Would free-riding on other (non-recommending) brokers reduce the ability of the recommending broker to benefit? Finally, why would clients continue to use full-service brokers in the presence of discount brokers who charge lower commissions?

When a client becomes aware of a broker's recommendation, and wishes to act on that recommendation, the client might choose to trade using the services of the recommending full-service broker, motivated by the desire to reward the broker for the information received in order to maintain and strengthen the relationship. The client would, of course, realize that in the absence of such reward, the information service could cease to exist. We refer to this

\footnotetext{
${ }^{1}$ Hence, it is frequently observed that compared to dealer-driven markets, order-driven markets provide greater transparency but lower liquidity.
} 
motivation as the 'reward effect'. This response is consistent with the documented effect of tipping in Irvine et al. (2007) whereby some full-service brokers provide selected clients with early access to forthcoming recommendations. However, clients of full-service brokers face higher brokerage costs than those charged by discount brokers. As their label implies, "discount" brokers charge lower commissions than other brokers. Full-service brokers have higher cost structures than discount brokers because research is costly to undertake: analysts must be paid and resources such as databases must be purchased. These costs can be recouped through higher commissions. In contrast, discount brokers predominantly offer only transaction services. As a result, there could be the need for further economic benefits or rationales to entice these clients to use the full-service broker to conduct the trade. One possible rationale is that recommendations are not the only attraction offered by full-service brokers compared to discount brokers. These extra attractions might include not only tips but also higher liquidity, a better bid-ask spread and a lower market impact.

Numerous traders maintain accounts with more than one broker, including discount brokers who offer the trading service at a lower commission. ${ }^{2}$ Because any one broker can have hundreds or even thousands of clients, once a recommendation is released to all clients it is, in effect, publicly available information. The client of a full-service broker who receives the recommendation can in this instance decide to trade through their account with a discount broker. Furthermore, this recommendation may be passed onto others in the market and clients of any broker can trade in response to the recommendation even though they are not clients of the broker making the recommendation. In these situations, free riding will occur and could be especially large in the case of discount brokers because of their lower commissions but is not necessarily limited to that group. Our objective is to investigate the tension between these two effects. More specifically, we measure and compare the impacts of the reward or tipping effect and the free-riding effect on the daily trading volume transacted by recommending brokers compared to non-recommending brokers in an orderdriven market.

Full-service stock brokers are motivated to regularly produce and release analyst investment recommendations to their clients in the hope that such forecasts will induce more transactions

\footnotetext{
${ }^{2}$ Reports in the Australian financial press suggest that around one-third of broking clients in Australia use multiple accounts, and that 'having access to a broad range of research' is a major reason to have multiple accounts. See Tolhurst (2012). Similarly, the website StockMarket.com.au, after reviewing the pros and cons of full-service and discount brokers, observes 'You could always try a combination of brokers'.
} 
for them in the short term and/or in the long term, hence earning the broker more trading commissions. A short-term response in trading volume is expected if clients find a recommendation persuasive and choose to transact while the information underlying the recommendation remains current. A long-term response is expected if the recommendation is part of a wider package of services provided by the broker to encourage the client to remain loyal. A short-term response should be easier to detect and, we argue, is a highly credible signal that a broker's clients value its analyst recommendations. Given the potential significance of the short-term response to analyst recommendations, it is surprising that there are only four studies directly investigating this phenomenon. These four studies are Irvine (2004), Irvine et al. (2007), Juergens and Lindsey (2009) and Lepone et al. (2012).

Irvine (2004) studied the Toronto market, where the trading system was primarily orderdriven, supplemented with market makers when liquidity was lacking. Irvine et al. (2007) study US stocks where their sample presumably covers both NYSE and NASDAQ. J\&L studied NASDAQ, where the trading system is based on market makers. Lepone et al. (2012), like us, also study the Australian Securities Exchange (ASX) but examine order flow imbalance rather than volume traded.

$\mathrm{J} \& \mathrm{~L}$ find that recommending brokers are rewarded with higher trading volumes and this effect is observed on the day a recommendation change is made but is also observed in the two days prior to the release of a recommendation change. J\&L conclude that recommending brokers are rewarded by traders with higher volumes as a form of compensation for the costs of undertaking research.

While our study is similar to J\&L, we adapt their method to suit the ASX trading environment. It provides the first evidence to support the generalization of the J\&L results for a predominantly dealer-driven US market to the central limit order-driven markets that are common in the international setting. By including so-called 'discount brokers', we also investigate whether there is a tendency for traders to free ride on the recommendations of full-service brokers. We find that the reward effect easily outweighs any free-riding effect. Like J\&L, we find that volume effects begin up to three days prior to a recommendation release. Although we find an effect on the sell orders similar to J\&L on the day prior to the release date, we also find this effect in the buy orders in response to recommendation upgrades for the three days prior to the release date. 
The remainder of the paper is organized as follows. Section 2 provides a literature review, a summary of the institutional background and the development of hypotheses. In Section 3 the data and methodology are outlined, while Section 4 presents and discusses the results. Section 5 concludes.

\section{Literature review, institutional background and hypothesis development}

Irvine (2004) provides evidence for a sample of 835 earnings forecasts and associated recommendations for 96 stocks listed on the Toronto Stock Exchange. The time period of the study is the 12 months from September 1, 1993 to August 31, 1994. Irvine's main concerns are the links between earnings forecasts, the broker's market share of trades in the recommended stock, and the broker's decision to cover the stock but he also reports results that link the recommendation level (such as 'buy' or 'sell') to the broker's market share. Irvine concludes that buy recommendations lead to a higher market share for the recommending broker. Unexpectedly, he also finds that after a buy recommendation, the broker's market share increases for both buy orders and sell orders. However, the results for sell recommendations were less pronounced than those for buy recommendations, perhaps because there were only 82 sell or strong sell recommendations in the sample. Irvine concludes that a broker's market share is positively related to its coverage decision.

For our purposes, Irvine's study provides useful background and suggests hypotheses worthy of study. Nevertheless, there are four aspects of his study that limit its direct relevance to us. First, research now focuses more on recommendation changes than recommendation levels (see, for example, Stickel 1995, Womack 1996, Francis and Soffer 1997, Harris and Ho 1998, Jegadeesh et al. 2004 and Howe et al. 2009). Second, the time period studied pre-dates the growth of internet-based trading, which has played an important role in the growth of discount brokers. Third, the sample of recommendations is reasonably small, especially for some relevant sub-samples such as negative recommendations. Fourth, the sample covers a limited time period of only 12 months.

Irvine et al. (2007) is more relevant to our study. Irvine et al. study only buy recommendations made in an initiation of coverage, which is defined as a particular broker releasing a recommendation on a particular stock for the first time. They study 9065 such initiations over two separate time periods of March 31, 1996 to December 31, 1997 and March 31, 2000 to December 31, 2000 which is a total of 30 months. Irvine et al. state that 
one reason for studying initiations, rather than ordinary recommendations, is that initiations are less likely to be clustered around confounding events. They find that the volumes traded by institutional investors increase in the five days prior to the release of the recommendation, a pattern which is consistent with brokers providing tips (leakages) to selected clients as to the content of the forthcoming recommendation announcement. Trading on these tips was on average profitable.

Lepone et al. (2012) study the ASX but, as they state (p. 258), their work is an extension of Irvine et al. Unlike Irvine et al., Lepone et al. study recommendation changes rather than buy initiations. They also analyze their results separately according to the size and reputation of the broker making the recommendation. The central metric used by Lepone et al. is the 'order flow imbalance' which is defined as the proportion of a broker's trading volume in a stock that is buyer-initiated. ${ }^{3}$ Their main findings are that order flow imbalance begins to behave abnormally approximately five days before a recommendation change is released and that trading on the basis of advance information of the recommendation change is profitable. They conclude that there is unequal access to analysts' research results in that there appear to be many instances of information leakage (or tipping).

The Juergens and Lindsey (2009) study is directly related to ours. J\&L examine the trading volume of NASDAQ market makers from August 23, 2004 to March 16, 2005. Their sample consists of 5881 recommendation changes. To address the issue of confounding events they employ a large number of dummy variables. When a recommendation change occurs, they observe and test the volume of trading in the days surrounding the recommendation release transacted by the recommending (or, 'affiliated') market maker compared to the volume of trading transacted by other ('unaffiliated') market makers. They find a disproportionate increase in the trading volume of affiliated market makers. In the case of recommendation downgrades they find evidence of a volume reaction two days before the release of the recommendation, suggesting that some clients have foreknowledge of the recommendation change. They conclude that increased volume is a form of compensation for the costs of analyst research.

\footnotetext{
${ }^{3}$ The metric of order flow imbalance is not appropriate to address our core research question; rather, as we explain shortly, the total volume traded is required because our focus is on the compensation that brokers receive for the costs of the research they undertake.
} 
The timing of these effects depends on when the client 'becomes aware' of the broker's recommendation. The evidence reported by, in particular, Lepone et al. (2012) for Australia, but also by Irvine et al. (2007), J\&L (2009) and Christophe et al. (2010) for the US and Anderson and Martinez (2010) for Sweden, strongly suggests that brokers' clients frequently become aware of a forthcoming recommendation several days before the release is made public. Hence, we expect to see volume responses in the two or three days before a recommendation release. Consequently, evidence on the reward and free-riding effects needs to be assessed not only at the time a recommendation is released but also in the two or three days prior to a release.

\section{Data and method}

Analysts' recommendations on stocks listed on the Australian Securities Exchange (ASX) are obtained from the Institutional Broker Estimates System (I/B/E/S). Each recommendation is expressed on a five-point scale of 1 ('sell'), 2 ('underperform'), 3 ('hold'), 4 ('buy') and 5 ('strong buy') 4 . Our sample begins on January 1, 2001 and terminates on December 31, 2004. ${ }^{5}$ For each recommendation in the sample we collect the release date of the recommendation, the stock name and code, the I/B/E/S broker full name, broker ID and abbreviated broker code. We exclude recommendations that are reiterations.

Information on daily buy and sell volumes, total volumes (defined as the sum of buy volumes and sell volumes), the number of trades and the dollar value of trades for every broker on the ASX for each of the ASX200 firms ${ }^{6}$ were downloaded from the Broker Share History files of IRESS on a daily frequency. ${ }^{7}$ We also collected the ASX/IRESS broker code and full broker name. The IRESS database includes full-service brokers and discount brokers.

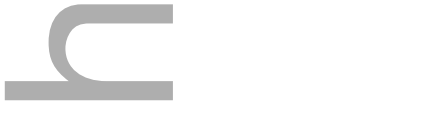

\footnotetext{
${ }^{4}$ In fact, I/B/E/S codes run in the reverse direction from 1 ('strong buy') to 5 ('sell'). We reverse this coding so that downgrades (for example, from 'strong buy' to 'underperform') register as negative numbers, while upgrades register as positive numbers. This procedure is consistent with, for example, Krische and Lee (2000), Leone and Wu (2002) and Agrawal and Chen (2008).

${ }^{5}$ In 2005, the ASX ceased disclosing the broker share history file on IRESS, which forces us to terminate our sample period at the end of 2004. Further, in 2006, I/B/E/S ceased disclosing the full broker name and provided only abbreviated broker codes.

${ }^{6}$ The ASX200 is an index of 200 firms which meet various market capitalization, liquidity and free-float criteria. Firms in the index are typically among the largest listed on the ASX. Any firm in the ASX200 at the beginning of a calendar year was included in our sample of firms for that calendar year.

${ }^{7}$ IRESS is the principal provider of market information on a real time and historical basis for the Australian market and is the industry standard for share market information. Prior to changing its name to IRESS Market Technology Ltd, it was known as BridgeDFS (part of Bridge News Service). This information was obtained from http://www.iress.com/en/Company_Profile/Company_overview/Our_history.html; accessed September 3, 2015 .
} 
The I/B/E/S and ASX/IRESS datasets were then merged. For a broker to be considered a full-service broker, the broker names had to be able to be matched across both the $\mathrm{I} / \mathrm{B} / \mathrm{E} / \mathrm{S}$ and ASX/IRESS datasets. In addition, an extensive search was performed on the Lexis-Nexis news database over this period to find news articles about the types of services provided by various brokers and to obtain information on mergers between brokers. We also examined the websites of broking firms to find evidence that they issue analyst reports and consider themselves to be full-service brokers. Discount brokers were identified using the 2003 Australian Investors Association discount brokers survey. This list was matched with the IRESS broker names and followed up with a search through Lexis-Nexis and the websites of brokers identified as discount brokers. Our initial sample consists of 26 full-service brokers and seven discount brokers. Daily share price returns are taken from the SIRCA daily price dataset and market capitalization data from the AGSM Share Price and Price Relative file.

The ASX operates an order-driven system with a central limit book. In effect, this structure means that every broker can trade in every stock; hence, no broker is officially identified as specifically allocated to trading in a particular stock. This feature precludes us from replicating the J\&L methodology, which is designed for a market maker system. However, the methodology we use is true to the spirit of their methodology.

When a broker changes its recommendation on a particular stock on day t, the universe of brokers can be split into five mutually exclusive and exhaustive categories. These categories are:

(i) the full-service broker which makes the recommendation on day t; other full-service brokers which make recommendations on (i.e. 'follow') ${ }^{8}$ that stock and who have released a recommendation change on the same stock within -3 days to +3 days relative to day $\mathrm{t}$;

(iii) other full-service brokers who make recommendations on (i.e. 'follow') that stock but who have not released a recommendation change on the same stock within -3 days to +3 days relative to day $\mathrm{t}$;

(iv) full-service brokers who do not follow that stock; and

\footnotetext{
${ }^{8}$ We define 'following a stock' as a broker who has released a recommendation on that stock within the previous 12 months. A similar definition is used by Mikhail, Walther and Willis (2007).
} 
Category (i) is the same as J\&L's affiliated market maker. Like J\&L, our main focus is on the volume traded by the recommending broker around the time of a recommendation change. Our main hypothesis is that there will be a large positive volume effect for this category. If there is leakage of information prior to its official release, then this effect may be observed prior to the release date. Evidence of such a response would make a significant contribution to the economic justification for full-service brokers to continue to bear the cost of making recommendations to clients.

Instead of J\&L's single alternative category of unaffiliated market makers, we have four other categories. For each of these other categories, the response will reflect two opposing effects: reward for information production and free riding. To the extent that investors reward the recommending broker, the effect on these categories will be negative, but if free riding predominates the effect will be positive. Categories (ii), (iii) and (iv) consist of various classes of full-service brokers. If the response of investors is concentrated in trading through the recommending broker (the reward effect) then the business undertaken by other brokers should be either negatively affected or unaffected. However, positive effects will be observed if clients channel trades through these brokers in order to ensure their continued access to non-transaction services such as receiving analyst recommendations and being offered opportunities to participate in IPOs. Positive volume effects for these categories might also be observed because institutional traders may spread their orders across several brokers in order to disguise their trading decisions (Goldstein et al. 2009). It is also possible that when a broker downgrades a particular stock, selling volume may be directed through brokers in these categories because the shares to be sold are held in that broker's name. Taken together, categories (i), (ii) and (iii) parallel J\&L's focus on market makers. By definition, a market maker in a particular stock is known to have a particular identification with that stock; full-service brokers who are known to follow a particular stock are a comparable group. Positive effects may also be observed in the case of category (v) - the discount brokers. The attraction of trading through a discount broker is, of course, the lower commission cost involved. If free riding is widespread, we expect a positive response in the volume of business transacted through the discount brokers because they provide the leastcost method of free riding. 
As in J\&L, in our methodology an 'event day' is defined as a day on which a broker has changed its recommendation on a particular stock. We refer to such an event as a 'recommendation change', ${ }^{9}$ the broker involved is the 'recommending broker' and the stock is the 'recommended stock'. Our main dependent variable is total volume but we also report results where the dependent variable is market share, proportional buy volume and proportional sell volume. Total volume is defined as the sum of the number of shares traded by the category being analyzed. Unlike J\&L, we run separate regressions for each of the five categories of broker, which we use to draw inferences about the effect of a recommendation change on each of our broker categories. Similar to J\&L, our methodology relies heavily on dummy variables to capture the impact of a recommendation change, together with control variables designed to capture aspects of the information environment. The control variables we use are very similar to those used by $\mathrm{J} \& \mathrm{~L}$.

The first regression equation is:

$$
\begin{aligned}
\text { L_TotVol0 }= & \beta_{0}+\beta_{1} \mathrm{D} \_\mathrm{UpR}+\beta_{2} \mathrm{D} \_\mathrm{DownR}+\beta_{3} \mathrm{D} \_\mathrm{Up} 1+\beta_{4} \mathrm{D} \_\mathrm{Up} 2+\beta_{5} \mathrm{D} \_\mathrm{UpMT} 2 \\
& +\beta_{6} \mathrm{D} \_\mathrm{Down} 1+\beta_{7} \mathrm{D} \_\mathrm{Down} 2+\beta_{8} \mathrm{D} \_\mathrm{DownMT} 2+\beta_{9} \mathrm{~L} \_\mathrm{AnCov} \\
& +\beta_{10} \mathrm{~L} \_\mathrm{MCAP}+\beta_{11} \mathrm{EDR}+\beta_{12} \mathrm{P} 3 \mathrm{DR}+\beta_{13} \mathrm{BMK}+\beta_{14} \mathrm{AGGVOL}+\beta_{15} \mathrm{TOP} 5 \\
& +\varepsilon_{\mathrm{t}}
\end{aligned}
$$

\begin{tabular}{|c|c|}
\hline Variable & Description \\
\hline L_TotV & $\begin{array}{l}\text { Natural log of the total volume traded in the recommended stock on the recommendation } \\
\text { day (day 0), for whichever category is the subject of the regression; that is, either (i) the } \\
\text { recommending broker, (ii) brokers who follow the stock and have released a } \\
\text { recommendation within } \pm 3 \text { days, (iii) brokers who follow the stock but have not released } \\
\text { a recommendation within } \pm 3 \text { days, (iv) full-service brokers who do not follow the stock } \\
\text { and (v) discount brokers. }\end{array}$ \\
\hline Mkt_Share0 & $\begin{array}{l}\text { Market share defined as the total volume for any of the broker category (i) to (v) for stock } \\
\text { i divided by the total volume for stock } i \text { on day } 0 \text {. We use the logit transformation as in }\end{array}$ \\
\hline
\end{tabular}

The variables in equation (1) are defined in Table 1 while Table 2 provides the summary statistics and market returns for the data set.

\section{Table 1 : Variable Definitions}

\footnotetext{
${ }^{9}$ Following J\&L, we define upgrades to include initiating recommendations that are in the strong buy category and we define downgrades to include initiating recommendations that are in the hold, underperform or sell categories. An initiating recommendation is one where the previous recommendation (if any) by that broker on that stock occurred more than 12 months previously.
} 


\begin{tabular}{|c|c|}
\hline & Juergens and Lindsey (2009). \\
\hline Prop_Buy0 & $\begin{array}{l}\text { Proportional buy volume defined as the buy volume for stock i of any of the broker } \\
\text { categories (i) to (v) on day } 0 \text { divided by total volume for that broker category on day } 0 . \\
\text { We use the logit transformation as in Juergens and Lindsey (2009). }\end{array}$ \\
\hline Prop_sel & $\begin{array}{l}\text { Proportional sell volume defined as the sell volume for stock i of any of the broker } \\
\text { categories (i) to (v) on day } 0 \text { divided by total volume for that broker category on day } 0 . \\
\text { We use the logit transformation as in Juergens and Lindsey (2009). }\end{array}$ \\
\hline D_UpR & Dummy variable where recommendation change is an upgrade. \\
\hline D_DownF & Dummy variable where recommendation change is a downgrade. \\
\hline D_Up1 & $\begin{array}{l}\text { Dummy variable in the event window (days } t-3 \text { to } t+3 \text { ) where there is an upgrade } \\
\text { issued by one full-service broker other than the recommending broker. }\end{array}$ \\
\hline D_Up2 & $\begin{array}{l}\text { Dummy variable in the event window (days } t-3 \text { to } t+3 \text { ) where there is an upgrade } \\
\text { issued by two full-service brokers other than the recommending broker. }\end{array}$ \\
\hline D_UpM & $\begin{array}{l}\text { Dummy variable in the event window (days } t-3 \text { to } t+3 \text { ) where there is an upgrade } \\
\text { issued by more than two full-service brokers other than the recommending broker. }\end{array}$ \\
\hline $\mathrm{D}$ & $\begin{array}{l}\text { Dummy variable in the event window (days } t-3 \text { to } t+3 \text { ) where there is a downgrade } \\
\text { issued by one full-service broker other than the recommending broker. }\end{array}$ \\
\hline & $\begin{array}{l}\text { Dummy variable in the event window (days } t-3 \text { to } t+3 \text { ) where there is a downgrade } \\
\text { issued by two full-service brokers other than the recommending broker. }\end{array}$ \\
\hline D_Dow & $\begin{array}{l}\text { Dummy variable in the event window (days } t-3 \text { to } t+3 \text { ) where there is a downgrade } \\
\text { upgrade issued by more than two full-service brokers other than the recommending } \\
\text { broker. }\end{array}$ \\
\hline L_Ancov & $\begin{array}{l}\text { The natural log of the number of analysts covering the stock in the month of the } \\
\text { recommendation }\end{array}$ \\
\hline L_Mcap & $\begin{array}{l}\text { The natural log of the market capitalization of the recommended stock as at the end of the } \\
\text { month prior to the recommendation month. }\end{array}$ \\
\hline EDR & The net-of-market return for the recommended stock on the recommendation day. \\
\hline P3DR & $\begin{array}{l}\text { The cumulative net-of-market return for the recommended stock in the } 3 \text { days prior to the } \\
\text { recommendation day. }\end{array}$ \\
\hline BMK & $\begin{array}{l}\text { A benchmark variable, defined as the natural log of the 'normal' volume traded in the } \\
\text { recommended stock on non-event days for the broker category (i) to (v) being analyzed. } \\
\text { The benchmark is the mean of the dependent variable on all trading days in the six } \\
\text { months prior to day 0, excluding trading days that fall in an event window (from }-3 \text { to }+3 \\
\text { days) for the recommended stock for the broker category being analyzed. }\end{array}$ \\
\hline AGGVOL & Aggregate volume traded by full-service and discount brokers. \\
\hline TOP5 & $\begin{array}{l}\text { Dummy variable if the recommending broker is one of the Top } 5 \text { brokers. A Top } 5 \\
\text { broker is defined as one ranked within the top } 5 \text { brokers as reported by East Coles, which } \\
\text { provides a ranking similar to the All American Institutional Ranking of Analysts. }\end{array}$ \\
\hline
\end{tabular}


The equation is estimated using ordinary least squares with White's heteroscedasticity adjustment. ${ }^{10}$ The results for the total volume as the dependent variable are presented in Panel A of Table 3.

We also run regressions using three other dependent variables: the market share of the broker category, the proportion of the buy orders traded by the broker category and the proportion of the sell orders traded by the broker category. The independent variables are the same as those used in the main equation except that AGGVOL is re-defined to be consistent with the dependent variable. For example, when the proportion of the buy orders traded by the broker category is the dependent variable, AGGVOL is defined as total volume of trading undertaken by that broker category on the day of the recommendation change ${ }^{11}$. These equations are estimated using a Tobit regression. The results are reported in Panels B, C and D of Table 3. We then turn our attention to four volume effects in the three-day period prior to the release of the recommendation for each of the four dependent variables. The results are reported in Panels A, B, C and D of Table 4 respectively.

\section{Results}

As an initial overview of the data, we provide in Table 2 the descriptive statistics of the sample and evidence on the mean net-of-market return on day 0 for upgrades and downgrades, by magnitude of the change in recommendation, and for initiations. From Table 2, Panel A, the average market capitalization of the sample is slightly more than A $\$ 5$ billion. The average number of broking firms following a stock is 5.28. The major observation in Panel A is that the variables are generally positively skewed. In Panel B, given the total volume traded on recommendation day, the recommending broker achieved $8.15 \%$ of the total volume traded while other brokers which followed the stock and had issued a recommendation within three days achieved only $5.89 \%$ of the total volume as a group. Discount brokers as a group achieved only $9.89 \%$ of the total volume.

\section{Table 2 : Summary Statistics and Returns}

\footnotetext{
${ }^{10}$ We have also run our regressions without the variable TOP5. The results are qualitatively unchanged.

${ }^{11}$ Consistent with J\&L, AGGVOL is not included in the regression when the dependent variable is market share.
} 
Panel A: This table shows the mean, median and standard deviation of selected variables on the day of and relative to the recommendation date. The market capitalization is recorded in millions.

\begin{tabular}{|c|c|c|c|}
\hline Variable & Mean & Median & $\begin{array}{l}\text { Standard } \\
\text { Deviation }\end{array}$ \\
\hline Market Capitalization (A \$ million) & 5,021 & 1,757 & 8,799 \\
\hline $\begin{array}{l}\text { Number of broking firms issuing } \\
\text { recommendation per stock }\end{array}$ & 5.280 & 4.000 & 3.746 \\
\hline $\begin{array}{l}\text { Total Volume traded on day of } \\
\text { recommendation } \\
\text { (in millions of shares) }\end{array}$ & 217.891 & 2.897 & 1.832 \\
\hline $\begin{array}{l}\text { Volume of Recommending Broker on day } 0 \\
\text { (in millions of shares) }\end{array}$ & 1.832 & 0.093 & 1.526 \\
\hline $\begin{array}{l}\text { Volume of brokers on day } 0 \text { following stock } \\
\text { and release information within } 3 \text { days of } \\
\text { recommending broker } \\
\text { (in millions of shares) }\end{array}$ & 1.074 & 0.176 & 2.971 \\
\hline $\begin{array}{l}\text { Volume of brokers following stock on day } 0 \\
\text { and do NOT release information within } 3 \text { days } \\
\text { of recommending broker } \\
\text { (in millions of shares) }\end{array}$ & 2.274 & 0.635 & 5.965 \\
\hline $\begin{array}{l}\text { Volume of brokers on day } 0 \text { who do not follow } \\
\text { the stock } \\
\text { (in millions of shares) }\end{array}$ & 2.238 & 0.828 & 4.622 \\
\hline $\begin{array}{l}\text { Volume on day } 0 \text { of discount brokers } \\
\text { (in millions of shares) }\end{array}$ & 0.578 & 0.145 & 1.722 \\
\hline D_UpR & 0.459 & 0 & 0.498 \\
\hline D_DownR & 0.541 & 0 & 0.497 \\
\hline D_Up1 & 0.073 & 0 & 0.260 \\
\hline D_Up2 & 0.007 & 0 & 0.083 \\
\hline D_UpMT2 & 0.000 & 0 & 0.021 \\
\hline D_Down1 & 0.088 & 0 & 0.284 \\
\hline D_Down2 & 0.011 & 0 & 0.106 \\
\hline D_DownMT2 & 0.002 & 0 & 0.048 \\
\hline
\end{tabular}




\begin{tabular}{|l|l|l|l|}
\hline Analyst Coverage & 10.135 & 10 & 3.101 \\
\hline
\end{tabular}

\section{Panel B : Breakdown of Volume on Recommendation Day}

This table shows the volume of shares traded by each of the five categories of brokers on the recommendation day

\begin{tabular}{|l|c|c|}
\hline Categories of Brokers & $\begin{array}{c}\text { Total Volume of shares for } \\
\text { the full sample on day 0 } \\
\text { (in millions of shares) }\end{array}$ & \% \\
\hline Volume of the Recommending Broker on day 0 & 3347.10 & $8.15 \%$ \\
\hline $\begin{array}{l}\text { Total Volume of brokers on day 0 following } \\
\text { stock and release information within 3 days of } \\
\text { recommending broker }\end{array}$ & 2421.66 & $5.89 \%$ \\
\hline $\begin{array}{l}\text { Total Volume of brokers following stock on day } \\
\text { 0 and do NOT release information within 3 days } \\
\text { of recommending broker }\end{array}$ & 15474.30 & $37.66 \%$ \\
\hline $\begin{array}{l}\text { Total Volume of brokers on day 0 who do not } \\
\text { follow the stock }\end{array}$ & 15785.86 & $38.42 \%$ \\
\hline Total Volume on day 0 of discount brokers & 4063.93 & $9.89 \%$ \\
\hline Total Volume of all brokers & 41092.85 & $100.00 \%$ \\
\hline
\end{tabular}




\section{Panel C : Summary of Returns on Recommendation Days}

Panel (i) presents net-of-market returns on recommendation days (day 0) for upgrades and downgrades separately. Panel (ii) presents net-of-market returns on recommendation days (day 0) by magnitude of upgrade and downgrade. Panel (iii) presents day 0 mean net-of-market returns for initiating recommendations, by recommendation level. The t-statistics represent whether the returns on day 0 are statistically different from zero. Following Juergens and Lindsey (2009), we exclude 'buy' initiations. An initiating recommendation is a recommendation released by a broker on a stock on which that broker has not released a recommendation for at least 12 months. Superscripts ***,**,* represent the $1 \%, 5 \%$ and $10 \%$ significance levels respectively.

\begin{tabular}{|c|c|c|c|}
\hline \multicolumn{4}{|c|}{ Panel (i) All Upgrades and Downgrades } \\
\hline Recommendation change & Mean returns & t-statistic & $\mathbf{N}$ \\
\hline Upgrades & $0.00134 * *$ & 2.52 & 2398 \\
\hline Downgrades & $-0.00209 * * *$ & -3.05 & 2669 \\
\hline \multicolumn{4}{|c|}{ Panel (ii) : Magnitudes of Recommendation Changes } \\
\hline Change in magnitude & Mean returns & t-statistic & $\mathbf{N}$ \\
\hline & -0.00039 & -0.07 & 9 \\
\hline+3 & 0.00615 & 1.01 & 26 \\
\hline+2 & $0.00174 *$ & 1.90 & 654 \\
\hline+1 & $0.00125^{*}$ & 1.83 & 1,592 \\
\hline & -0.00121 & -1.46 & 1,679 \\
\hline-2 & $-0.00434 * * *$ & -3.18 & 708 \\
\hline-3 & -0.00526 & -0.58 & 33 \\
\hline-4 & -0.00126 & -0.27 & 23 \\
\hline \multicolumn{4}{|c|}{ Panel (iii) Initiating Recommendations } \\
\hline Recommendation & Mean returns & t-statistic & $\mathbf{N}$ \\
\hline Strong buy & -0.00711 & -0.37 & 117 \\
\hline Hold & -0.00261 & -0.75 & 179 \\
\hline Sell & 0.00110 & 0.35 & 25 \\
\hline Strong sell & 0.00687 & 1.62 & 22 \\
\hline
\end{tabular}

From Table 2, Panel C, the mean responses for both upgrades and downgrades are consistent with the direction of the recommendation signal, with upgrades producing a mean positive This article is protected by copyright. All rights reserved 
return of $0.134 \%$ and downgrades producing a mean negative return of $0.209 \%$. Both are significant at the 5\% level. Qualitatively, these results are similar to those of J\&L, although quantitatively they are much smaller. Of the eight levels of magnitude changes, only three (upgrades of one and two ranks and downgrades of two ranks) are significant. None of the four initiation levels is statistically significant. These results, while not inconsistent with those of $J \& L$, are weaker than the corresponding results reported by $J \& L$.

In Table 3, we present the results of our tests of volume responses on the day of the release of a recommendation change. The dependent variables are: total volume, market share, proportional buy volume and proportional sell volume and the results are reported in Panels A, B, C and D, respectively. In each panel, we report the result of five regressions corresponding to the five categories of brokers. In each regression our main focus is on the coefficients of the dummy variables for recommendation upgrades and recommendation downgrades.

The results in Panel A show that, contrary to our expectations, the volume responses on the day of a recommendation change are overwhelmingly negative across the broker categories. ${ }^{12}$ For recommending brokers, this negative response is significant at the $10 \%$ level for upgrades and at the $1 \%$ level for downgrades. Three of the responses for broker categories (ii) to (v) are significantly negative for upgrade recommendations and all four are significantly negative for downgrades. Hence, there is strong evidence that when a recommendation change is released, there is a significantly negative effect on total volumes traded by virtually all broker categories, for both upgrades and downgrades. ${ }^{13}$

The results in Panel B show a significantly positive effect of upgrades on the market share of both the recommending broker and of brokers who follow the stock and made a recommendation change within the window but not on day 0 . For those brokers who follow the stock but who did not issue a recommendation change in the window, there is a significantly negative relationship. For the downgrade dummy variable, the recommending broker has a positive statistical relationship at the $10 \%$ level while for brokers who follow the stock but did not issue a recommendation change in the window, there is a significantly negative relationship.

\footnotetext{
12 This result is consistent with short-term over-reaction and subsequent reversal. We thank an anonymous referee for this suggestion.

${ }^{13}$ To make use of the richer information environment of the five categories of brokers, we also placed them into one stacked regression. The results are relatively similar with regard to the significance and the sign of the coefficients.
} 
The results in Panel $\mathrm{C}$ give further support to the results in Panel A. Recommendation upgrades result in a significant increase in the proportion of 'buy' transactions undertaken by the recommending broker and those brokers who follow the stock and made a recommendation change within the window but not on day 0 . The results for the other broker categories are not significantly different from zero. In particular, the result for category (v) provides no evidence of free riding by trading through discount brokers. Panel D reports the corresponding results for the proportion of sell volumes. However, unlike the results in Panel C, nearly all the results in Panel D are not significantly different from zero. Again, there is no evidence of free riding.

\section{Table 3 : Regression Results on Recommendation Days}

Table 3 reports results from OLS regressions where the dependent variables are attributed volume measures in each stock on days with recommendation changes. Five categories of brokers are defined. These are:

(i) the broker whose recommendation was changed on day 0 (the 'recommending broker');

(ii) a broker who follows the stock and has released a recommendation change within the event window but not on day 0;

(iii) a broker who follows the stock but has not released a recommendation change within the event window;

(iv) a broker who is a full-service broker but does not follow the stock and

(vi) a broker who is a discount broker.

Dependent variables are:

(A) Total volume is the natural log of total volume traded on the recommendation day by the broker category; (B) Market share is the logit transformation of the proportion of total volume traded on the recommendation day by the broker category. The logit transformation follows Juergens and Lindsey (2009, p. 2335); (C) and (D) Proportional buy (sell) volume is the logit transformation of the proportion of total buy (sell) volume traded on the recommendation day by the broker category.

Recommendation upgrade (downgrade) is equal to 1 if the recommendation change is an upgrade (downgrade). The six "Following FSB" variables are dummy variables for recommendation changes released by full-service brokers other than the recommending broker in the period from day -3 to day +3 , excluding day 0 . For these variables Up (Down) refer to upgrades (downgrades), while 1, 2 and MT2 refer to the number of such brokers. For example, "Following FSBs Up2" is equal to 1 if, in this event window (days $t-3$ to $t+3$ ), there is an upgrade released by two full-service brokers other than the recommending broker; 0 otherwise. Benchmark is the average value of the dependent variable on a non-event day. Aggregate volume is the total volume traded in the stock on day 0 by all brokers. Variables for the information environment are also included. In parentheses, we report t-statistics. Superscripts $* * *, * *, *$ represent the $1 \%, 5 \%$ and $10 \%$ significance levels (two-tail test) respectively.

\begin{tabular}{llllll}
\hline Panel A: Total Volume & \multicolumn{7}{c}{} \\
\hline & $\begin{array}{c}\text { Broker } \\
\text { category (i) }\end{array}$ & $\begin{array}{c}\text { Broker } \\
\text { category (ii) }\end{array}$ & $\begin{array}{c}\text { Broker } \\
\text { category (iii) }\end{array}$ & $\begin{array}{c}\text { Broker } \\
\text { category (iv) }\end{array}$ & $\begin{array}{c}\text { Broker } \\
\text { category (v) }\end{array}$ \\
\hline Constant & & & & \\
& $-2.7773^{* * * *}$ & $-3.9639^{* * *}$ & $-2.2005^{* * *}$ & $-1.7429^{* * *}$ & 0.0621 \\
& $(-4.78)$ & $(-9.72)$ & $(-2.92)$ & $(-5.85)$ & $(0.23)$
\end{tabular}




\begin{tabular}{|c|c|c|c|c|c|}
\hline Recommendation upgrade & $\begin{array}{l}-0.2600 * \\
(-1.88)\end{array}$ & $\begin{array}{l}-0.1029 \\
(-1.27)\end{array}$ & $\begin{array}{l}-0.4240 * * \\
(-2.03)\end{array}$ & $\begin{array}{l}-0.2295 * * * \\
(-3.25)\end{array}$ & $\begin{array}{l}-0.2463 * * * \\
(-3.25)\end{array}$ \\
\hline Recommendation downgrade & $\begin{array}{l}-0.4729 * * * \\
(-3.43)\end{array}$ & $\begin{array}{l}-0.2046^{* *} \\
(-2.56)\end{array}$ & $\begin{array}{l}-0.5601 * * * \\
(-2.70)\end{array}$ & $\begin{array}{l}-0.2869 * * * \\
(-4.03)\end{array}$ & $\begin{array}{l}-0.2754 * * * \\
(-3.60)\end{array}$ \\
\hline Following FSBs Up1 & $\begin{array}{l}0.1592 \\
(1.36)\end{array}$ & $\begin{array}{l}0.2058 * * * \\
(2.76)\end{array}$ & $\begin{array}{l}0.0341 \\
(0.31)\end{array}$ & $\begin{array}{l}0.0144 \\
(0.27)\end{array}$ & $\begin{array}{l}0.1440 * * * \\
(2.84)\end{array}$ \\
\hline Following FS & $\begin{array}{l}0.5180 \\
(0.94)\end{array}$ & $\begin{array}{l}0.7879 * * * \\
(3.26)\end{array}$ & $\begin{array}{l}0.6934 * \\
(1.68)\end{array}$ & $\begin{array}{l}0.3689 \\
(1.14)\end{array}$ & $\begin{array}{l}0.9404 * * * \\
(2.84)\end{array}$ \\
\hline Following FSBs & $\begin{array}{l}1.5574 * * * \\
(9.30)\end{array}$ & $\begin{array}{l}0.8067 * * * \\
(7.99)\end{array}$ & $\begin{array}{l}0.9383^{* * *} \\
(3.44)\end{array}$ & $\begin{array}{l}1.0270^{* * * *} \\
(3.73)\end{array}$ & $\begin{array}{l}-0.1094 \\
(-0.70)\end{array}$ \\
\hline Following F & $\begin{array}{l}-0.0955 \\
(-0.74)\end{array}$ & $\begin{array}{l}-0.0288 \\
(-0.44)\end{array}$ & $\begin{array}{l}-0.1463 \\
(-1.34)\end{array}$ & $\begin{array}{l}0.0415 \\
(0.76)\end{array}$ & $\begin{array}{l}0.1919 * * * \\
(3.86)\end{array}$ \\
\hline Following FS & $\begin{array}{l}0.6510 * * \\
(2.04)\end{array}$ & $\begin{array}{l}0.2877 \\
(1.01)\end{array}$ & $\begin{array}{l}0.2383 \\
(1.09)\end{array}$ & $\begin{array}{l}0.4176^{* * *} \\
(2.67)\end{array}$ & $\begin{array}{l}0.6179 * * * \\
(4.18)\end{array}$ \\
\hline Following FSBs DownMT2 & $\begin{array}{l}0.5266 \\
(0.88)\end{array}$ & $\begin{array}{l}0.4916 \\
(1.04)\end{array}$ & $\begin{array}{l}0.1932 \\
(0.56)\end{array}$ & $\begin{array}{l}0.8245^{* *} \\
(2.10)\end{array}$ & $\begin{array}{l}0.2439 \\
(0.78)\end{array}$ \\
\hline Analyst cove & $\begin{array}{l}-0.1678^{*} \\
(-1.74)\end{array}$ & $\begin{array}{l}0.2781 * * * \\
(3.52)\end{array}$ & $\begin{array}{l}0.0373 \\
(0.33)\end{array}$ & $\begin{array}{l}0.3129 * * * \\
(5.50)\end{array}$ & $\begin{array}{l}0.0766^{*} \\
(1.68)\end{array}$ \\
\hline Market capita & $\begin{array}{l}0.2966^{* * * *} \\
(8.13)\end{array}$ & $\begin{array}{l}0.1898 * * * \\
(6.01)\end{array}$ & $\begin{array}{l}0.1502^{* * *} \\
(2.81)\end{array}$ & $\begin{array}{l}0.2025^{* * * *} \\
(5.65)\end{array}$ & $\begin{array}{l}0.0230 \\
(1.04)\end{array}$ \\
\hline Event-day ret & $\begin{array}{l}-1.0195 \\
(-0.74)\end{array}$ & $\begin{array}{l}-0.4296 \\
(-0.47)\end{array}$ & $\begin{array}{l}-0.6636 \\
(-0.34)\end{array}$ & $\begin{array}{l}-1.3521 \\
(-1.51)\end{array}$ & $\begin{array}{l}-2.2660 * * \\
(-2.15)\end{array}$ \\
\hline Prior 3-day 1 & $\begin{array}{l}-2.0531 * * * \\
(-3.38)\end{array}$ & $\begin{array}{l}-1.4202 * * * \\
(-3.71)\end{array}$ & $\begin{array}{l}-2.7764 * * * \\
(-3.48)\end{array}$ & $\begin{array}{l}-1.5493^{* * * *} \\
(-3.81)\end{array}$ & $\begin{array}{l}-2.4689 * * * \\
(-5.03)\end{array}$ \\
\hline Benchmark & $\begin{array}{l}0.9802 * * * \\
(31.05)\end{array}$ & $\begin{array}{l}0.7393 * * * \\
(18.41)\end{array}$ & $\begin{array}{l}0.9280 * * * \\
(44.87)\end{array}$ & $\begin{array}{l}0.5348 * * * \\
(7.90)\end{array}$ & $\begin{array}{l}0.8104 * * * \\
(18.41)\end{array}$ \\
\hline Aggregate volume & $\begin{array}{l}-0.2258 * * * \\
(-8.13)\end{array}$ & $\begin{array}{l}0.1521^{* * *} \\
(8.80)\end{array}$ & $\begin{array}{l}-0.0173 \\
(-0.57)\end{array}$ & $\begin{array}{l}0.2047 * * * \\
(11.63)\end{array}$ & $\begin{array}{l}0.1155^{* * * *} \\
(8.41)\end{array}$ \\
\hline Top 5 analyst & $\begin{array}{l}0.2060^{* *} \\
(2.21)\end{array}$ & $\begin{array}{l}0.2292 * * * \\
(3.68)\end{array}$ & $\begin{array}{l}0.2140 \\
(1.58)\end{array}$ & $\begin{array}{l}0.1471^{* * *} \\
(3.11)\end{array}$ & $\begin{array}{l}0.1659 * * * \\
(3.39)\end{array}$ \\
\hline Adjusted $\mathrm{R}^{2}$ & 0.441 & 0.599 & 0.830 & 0.478 & 0.593 \\
\hline
\end{tabular}

Table 3 : Regression Results on Recommendation Days (contd.)

Broker categories are:

(i) the broker whose recommendation was changed on day 0 (the 'recommending broker');

(ii) a broker who follows the stock and has released a recommendation change within the event window but not on day 0 ;

(iii) a broker who follows the stock but has not released a recommendation change within the event window;

(iv) a broker who is a full-service broker but does not follow the stock and

(v) a broker who is a discount broker.

\section{Panel B: Market Share}




\begin{tabular}{|c|c|c|c|c|c|}
\hline & $\begin{array}{l}\text { category } \\
\text { (i) }\end{array}$ & $\begin{array}{l}\text { category } \\
\text { (ii) }\end{array}$ & $\begin{array}{l}\text { category } \\
\text { (iii) }\end{array}$ & $\begin{array}{l}\text { category } \\
\text { (iv) }\end{array}$ & $\begin{array}{l}\text { category } \\
\text { (v) }\end{array}$ \\
\hline Constant & $\begin{array}{l}-18.904 * * * \\
(-24.86)\end{array}$ & $\begin{array}{l}-9.8861 * * * \\
(-14.56)\end{array}$ & $\begin{array}{l}-16.661 * * * \\
(-25.91)\end{array}$ & $\begin{array}{l}-3.1955^{* * * *} \\
(-10.47)\end{array}$ & $\begin{array}{l}-6.6236 * * * \\
(-19.10)\end{array}$ \\
\hline Recommendation upgrade & $\begin{array}{l}0.6389 * * * \\
(3.25)\end{array}$ & $\begin{array}{l}0.4267 * * * \\
(2.72)\end{array}$ & $\begin{array}{l}-0.3150 * * \\
(-2.15)\end{array}$ & $\begin{array}{l}-0.0537 \\
(-0.78)\end{array}$ & $\begin{array}{l}-0.0488 \\
(-0.67)\end{array}$ \\
\hline Recommendation downgrade & $\begin{array}{l}0.3825^{*} \\
(1.95)\end{array}$ & $\begin{array}{l}0.2550 \\
(1.61)\end{array}$ & $\begin{array}{l}-0.2960 * * \\
(-2.03)\end{array}$ & $\begin{array}{l}-0.0180 \\
(-0.27)\end{array}$ & $\begin{array}{l}-0.0475 \\
(-0.65)\end{array}$ \\
\hline Following FSBs Up1 & $\begin{array}{l}0.4863 * * * \\
(3.34)\end{array}$ & $\begin{array}{l}0.0140 \\
(0.12)\end{array}$ & $\begin{array}{l}2.6591 * * * \\
(13.53)\end{array}$ & $\begin{array}{l}-0.1092 \\
(-1.90)^{*}\end{array}$ & $\begin{array}{l}0.1053 * * \\
(2.15)\end{array}$ \\
\hline Following FSBs Up2 & $\begin{array}{l}-0.0296 \\
(-0.06)\end{array}$ & $\begin{array}{l}0.0143 \\
(0.04)\end{array}$ & $\begin{array}{l}2.5585^{* * * *} \\
(4.32)\end{array}$ & $\begin{array}{l}-0.0333 \\
(-0.14)\end{array}$ & $\begin{array}{l}0.3459 * * \\
(2.27)\end{array}$ \\
\hline Following FSBs $U_{1}$ & $\begin{array}{l}1.5058 * * * \\
(10.54)\end{array}$ & $\begin{array}{l}0.0952 \\
(0.24)\end{array}$ & $\begin{array}{l}1.2678 * * \\
(2.16)\end{array}$ & $\begin{array}{l}0.3925^{* * * *} \\
(3.61)\end{array}$ & $\begin{array}{l}-0.9084 * * * \\
(-4.72)\end{array}$ \\
\hline Following FSBs Dor & $\begin{array}{l}-0.1229 \\
(-0.81)\end{array}$ & $\begin{array}{l}-0.2889 * * * \\
(-2.58)\end{array}$ & $\begin{array}{l}2.4842 * * * \\
(13.66)\end{array}$ & $\begin{array}{l}0.0235 \\
(0.42)\end{array}$ & $\begin{array}{l}0.1855^{* * * *} \\
(3.40)\end{array}$ \\
\hline Following FSBs Dow & $\begin{array}{l}0.3383 \\
(0.91)\end{array}$ & $\begin{array}{l}-1.1433 * * * \\
(-2.75)\end{array}$ & $\begin{array}{l}1.0229 * \\
(1.87)\end{array}$ & $\begin{array}{l}0.0569 \\
(0.41)\end{array}$ & $\begin{array}{l}0.3408 * * * \\
(2.80)\end{array}$ \\
\hline Following FSBs DownMT2 & $\begin{array}{l}-0.5623 \\
(-0.55)\end{array}$ & $\begin{array}{l}-1.5436 \\
(-1.60)\end{array}$ & $\begin{array}{l}-1.1351 \\
(-0.72)\end{array}$ & $\begin{array}{l}0.6219 \\
(1.22)\end{array}$ & $\begin{array}{l}-0.1534 \\
(-0.39)\end{array}$ \\
\hline Analyst coverage & $\begin{array}{l}-0.2897 * * * \\
(-2.70)\end{array}$ & $\begin{array}{l}1.0557^{* * * *} \\
(7.49)\end{array}$ & $\begin{array}{l}0.0123 \\
(0.11)\end{array}$ & $\begin{array}{l}0.1407 * * * \\
(2.61)\end{array}$ & $\begin{array}{l}0.1453^{* * * *} \\
(3.27)\end{array}$ \\
\hline Market capitalization & $\begin{array}{l}0.5840 * * * \\
(15.98)\end{array}$ & $\begin{array}{l}0.2441 * * * \\
(6.42)\end{array}$ & $\begin{array}{l}0.2957 * * * \\
(8.74)\end{array}$ & $\begin{array}{l}0.0270 \\
(1.89)^{*}\end{array}$ & $\begin{array}{l}0.1063 * * * \\
(6.96)\end{array}$ \\
\hline Event-day return & $\begin{array}{l}-0.4595 \\
(-0.32)\end{array}$ & $\begin{array}{l}2.8932 * * \\
(2.11)\end{array}$ & $\begin{array}{l}-0.4775 \\
(-0.37)\end{array}$ & $\begin{array}{l}0.2052 \\
(0.42)\end{array}$ & $\begin{array}{l}-0.4734 \\
(-1.06)\end{array}$ \\
\hline Prior 3-day retur & $\begin{array}{l}0.2576 \\
(0.35)\end{array}$ & $\begin{array}{l}0.5025 \\
(0.74)\end{array}$ & $\begin{array}{l}0.1772 \\
(0.21)\end{array}$ & $\begin{array}{l}0.0236 \\
(0.09)\end{array}$ & $\begin{array}{l}-0.9173 * * * \\
(-3.28)\end{array}$ \\
\hline Benchmark & $\begin{array}{l}23.119 * * * \\
(37.81)\end{array}$ & $\begin{array}{l}0.7070 * * * \\
(3.02)\end{array}$ & $\begin{array}{l}38.260 * * * \\
(25.56)\end{array}$ & $\begin{array}{l}4.5483 * * * \\
(28.86)\end{array}$ & $\begin{array}{l}13.4522 * * * \\
(39.18)\end{array}$ \\
\hline Top 5 analyst & $\begin{array}{l}0.4473 * * * \\
(3.97)\end{array}$ & $\begin{array}{l}0.0937 \\
(1.11)\end{array}$ & $\begin{array}{l}0.1477 \\
(1.30)\end{array}$ & $\begin{array}{l}-0.0705 \\
(-1.48)\end{array}$ & $\begin{array}{l}0.0155 \\
(0.37)\end{array}$ \\
\hline Adjusted $\mathrm{R}^{2}$ & 0.235 & 0.125 & 0.605 & 0.199 & 0.324 \\
\hline
\end{tabular}

Table 3 : Regression Results on Recommendation Days (contd.)

Broker categories are:

(i) the broker whose recommendation was changed on day 0 (the 'recommending broker');

(ii) a broker who follows the stock and has released a recommendation change within the event window but not on day 0 ; 
(iii) a broker who follows the stock but has not released a recommendation change within the event window;

(iv) a broker who is a full-service broker but does not follow the stock and

(v) a broker who is a discount broker.

\section{Panel C: Proportional Buy Volume}

\begin{tabular}{|c|c|c|c|c|c|}
\hline (1) & $\begin{array}{c}\text { Broker } \\
\text { category } \\
\text { (i) }\end{array}$ & $\begin{array}{c}\text { Broker } \\
\text { category } \\
\text { (ii) }\end{array}$ & $\begin{array}{c}\text { Broker } \\
\text { category } \\
\text { (iii) }\end{array}$ & $\begin{array}{c}\text { Broker } \\
\text { category } \\
\text { (iv) }\end{array}$ & $\begin{array}{c}\text { Broker } \\
\text { category } \\
\text { (v) }\end{array}$ \\
\hline Constant & $\begin{array}{l}-24.221 * * * \\
(-30.41)\end{array}$ & $\begin{array}{l}-13.624 * * * \\
(-18.81)\end{array}$ & $\begin{array}{l}-18.132 * * * \\
(-30.45)\end{array}$ & $\begin{array}{l}-5.529 * * * \\
(-16.34)\end{array}$ & $\begin{array}{l}-9.517 * * * \\
(-19.96)\end{array}$ \\
\hline Recommendation upgrade & $\begin{array}{l}0.4824 * * * \\
(5.21)\end{array}$ & $\begin{array}{l}0.1969 * * * \\
(2.82)\end{array}$ & $\begin{array}{l}0.0245 \\
(0.37)\end{array}$ & $\begin{array}{l}-0.0018 \\
(-0.05)\end{array}$ & $\begin{array}{l}-0.105 \\
(-0.23)\end{array}$ \\
\hline Following FS & $\begin{array}{l}0.6305^{* * * *} \\
(3.87)\end{array}$ & $\begin{array}{l}0.0907 \\
(0.71)\end{array}$ & $\begin{array}{l}2.3376^{* * *} \\
(12.49)\end{array}$ & $\begin{array}{l}-0.0485 \\
(-0.92)\end{array}$ & $\begin{array}{l}0.1399 * * \\
(2.05)\end{array}$ \\
\hline Following FS & $\begin{array}{l}0.1470 \\
(0.28)\end{array}$ & $\begin{array}{l}-0.0320 \\
(-0.09)\end{array}$ & $\begin{array}{l}2.5897 * * * \\
(4.58)\end{array}$ & $\begin{array}{l}-0.3753 \\
(-1.09)\end{array}$ & $\begin{array}{l}0.2757 \\
(1.32)\end{array}$ \\
\hline Following FSBs L & $\begin{array}{l}-0.2779 \\
(-0.15)\end{array}$ & $\begin{array}{l}0.3828 \\
(1.15)\end{array}$ & $\begin{array}{l}1.4193 * * * \\
(3.11)\end{array}$ & $\begin{array}{c}0.2547 * * * \\
(6.31)\end{array}$ & $\begin{array}{l}-0.9731 \text { ** } \\
(-2.19)\end{array}$ \\
\hline Following FSBs Down1 & $\begin{array}{l}0.0193 \\
(0.12)\end{array}$ & $\begin{array}{l}-0.3110 * * \\
(-2.50)\end{array}$ & $\begin{array}{l}1.9090 * * * \\
(10.92)\end{array}$ & $\begin{array}{l}0.0141 \\
(0.25)\end{array}$ & $\begin{array}{l}0.2472 * * * \\
(3.53)\end{array}$ \\
\hline Following FSBs Down2 & $\begin{array}{l}0.5953 \\
(1.45)\end{array}$ & $\begin{array}{l}-0.9570^{* *} \\
(-2.43)\end{array}$ & $\begin{array}{l}0.8880 \\
(1.84)\end{array}$ & $\begin{array}{l}0.0773 \\
(0.57)\end{array}$ & $\begin{array}{l}0.4356 * * * \\
(2.97)\end{array}$ \\
\hline Following FSBs DownMT2 & $\begin{array}{l}-0.3939 \\
(-0.36)\end{array}$ & $\begin{array}{l}-1.1169 \\
(-1.33)\end{array}$ & $\begin{array}{l}-0.7734 \\
(-0.63)\end{array}$ & $\begin{array}{l}0.3479 \\
(1.07)\end{array}$ & $\begin{array}{l}0.0401 \\
(0.08)\end{array}$ \\
\hline Analyst coverage & $\begin{array}{l}-0.0506 \\
(0.42)\end{array}$ & $\begin{array}{l}1.2094 * * * \\
(8.60)\end{array}$ & $\begin{array}{l}0.0058 \\
(0.06)\end{array}$ & $\begin{array}{c}0.2016^{* * * *} \\
(3.59)\end{array}$ & $\begin{array}{l}0.1071 \\
(1.90)\end{array}$ \\
\hline Market capitalization & $\begin{array}{l}0.7321^{* * * *} \\
(17.77)\end{array}$ & $\begin{array}{l}0.3092 * * * \\
(7.64)\end{array}$ & $\begin{array}{l}0.2885^{* * *} \\
(8.71)\end{array}$ & $\begin{array}{c}0.0723 * * * \\
(4.35)\end{array}$ & $\begin{array}{l}0.2134 * * * \\
(9.38)\end{array}$ \\
\hline Event-day return & $\begin{array}{l}-1.0798 \\
(-0.71)\end{array}$ & $\begin{array}{l}2.8123 * * \\
(2.13)\end{array}$ & $\begin{array}{l}-0.0462 \\
(-0.04)\end{array}$ & $\begin{array}{l}0.3871 \\
(0.81)\end{array}$ & $\begin{array}{l}-4.4545^{* * *} \\
(-6.27)\end{array}$ \\
\hline Prior 3-day return & $\begin{array}{l}-0.5119 \\
(-0.63)\end{array}$ & $\begin{array}{l}0.5057 \\
(0.70)\end{array}$ & $\begin{array}{l}-0.4919 \\
(-0.67)\end{array}$ & $\begin{array}{l}-0.0512 \\
(-0.19)\end{array}$ & $\begin{array}{l}-1.9625 * * * \\
(-5.14)\end{array}$ \\
\hline Benchmark & $\begin{array}{l}48.222 * * * \\
(35.75)\end{array}$ & $\begin{array}{l}1.3762 * * * \\
(2.98)\end{array}$ & $\begin{array}{l}66.620 * * * \\
(25.64)\end{array}$ & $\begin{array}{l}7.4416 * * * \\
(24.42)\end{array}$ & $\begin{array}{l}26.3080 * * * \\
(30.83)\end{array}$ \\
\hline Aggregate volume & $\begin{array}{l}0.0226 \\
(0.94)\end{array}$ & $\begin{array}{l}0.0670 * * * \\
(3.29)\end{array}$ & $\begin{array}{c}0.0757 * * * \\
(5.04)\end{array}$ & $\begin{array}{l}0.0219 \\
(1.91)^{*}\end{array}$ & $\begin{array}{l}-0.0234 \\
(-1.78)^{*}\end{array}$ \\
\hline Top 5 analyst & $\begin{array}{l}0.4243 * * * \\
(3.37)\end{array}$ & $\begin{array}{l}0.1895 * * \\
(2.07)\end{array}$ & $\begin{array}{l}0.1741 \\
(1.67)^{*}\end{array}$ & $\begin{array}{l}0.0246 \\
(0.54)\end{array}$ & $\begin{array}{l}0.0724 \\
(1.37)\end{array}$ \\
\hline Adjusted $\mathrm{R}^{2}$ & 0.232 & 0.135 & 0.573 & 0.151 & 0.217 \\
\hline
\end{tabular}


Table 3 : Regression Results on Recommendation Days (contd.)
Broker categories are:
(i) the broker whose recommendation was changed on day 0 (the 'recommending broker');
(ii) a broker who follows the stock and has released a recommendation change within the event window but not on day 0;
(iii) a broker who follows the stock but has not released a recommendation change within the event window;
(iv) a broker who is a full-service broker but does not follow the stock and
(v) a broker who is a discount broker.

\begin{tabular}{|c|c|c|c|c|c|}
\hline \multicolumn{6}{|c|}{ Panel D: Proportional Sell Volume } \\
\hline & $\begin{array}{l}\text { Broker } \\
\text { category } \\
\text { (i) }\end{array}$ & $\begin{array}{c}\text { Broker } \\
\text { category } \\
\text { (ii) }\end{array}$ & $\begin{array}{c}\text { Broker } \\
\text { category } \\
\text { (iii) }\end{array}$ & $\begin{array}{c}\text { Broker } \\
\text { category } \\
\text { (iv) }\end{array}$ & $\begin{array}{c}\text { Broker } \\
\text { category } \\
\text { (v) }\end{array}$ \\
\hline Constant & $\begin{array}{l}-23.182 * * * \\
(-29.85)\end{array}$ & $\begin{array}{l}-14.217 * * * \\
(-19.77)\end{array}$ & $\begin{array}{l}-17.806^{* * *} \\
(-30.10)\end{array}$ & $\begin{array}{l}-5.711 * * * \\
(-15.91)\end{array}$ & $\begin{array}{l}-11.544 * * * \\
(-23.27)\end{array}$ \\
\hline Recommendation downgrade & $\begin{array}{l}0.0894 \\
(0.98)\end{array}$ & $\begin{array}{l}-0.1207 \\
(-1.72)^{*}\end{array}$ & $\begin{array}{l}0.0322 \\
(0.48)\end{array}$ & $\begin{array}{l}0.0257 \\
(0.71)\end{array}$ & $\begin{array}{l}0.0291 \\
(0.61)\end{array}$ \\
\hline Following FSBs & $\begin{array}{l}0.2477 \\
(1.44)\end{array}$ & $\begin{array}{l}-0.0310 \\
(-0.24)\end{array}$ & $\begin{array}{c}1.9657 * * * \\
(9.59)\end{array}$ & $\begin{array}{l}-0.0637 \\
(-0.96)\end{array}$ & $\begin{array}{l}0.1291 \\
(1.58)\end{array}$ \\
\hline Following FSBs & $\begin{array}{l}0.1825 \\
(0.36)\end{array}$ & $\begin{array}{l}0.3080 \\
(0.86)\end{array}$ & $\begin{array}{c}2.1348^{* * *} \\
(3.88)\end{array}$ & $\begin{array}{l}0.1496 \\
(0.82)\end{array}$ & $\begin{array}{c}0.5282 * * * \\
(2.77)\end{array}$ \\
\hline Following FSBs & $\begin{array}{l}2.4011^{* * * *} \\
(10.67)\end{array}$ & $\begin{array}{l}0.1747 \\
(0.34)\end{array}$ & $\begin{array}{l}1.6946 * * * \\
(3.04)\end{array}$ & $\begin{array}{c}0.6551 * * * \\
(5.64)\end{array}$ & $\begin{array}{c}-0.3058^{* * *} \\
(-4.00)\end{array}$ \\
\hline Following FSBs & $\begin{array}{l}0.0412 \\
(0.26)\end{array}$ & $\begin{array}{l}-0.1997 \\
(-1.69)^{*}\end{array}$ & $\begin{array}{l}1.8671 * * * \\
(10.17)\end{array}$ & $\begin{array}{l}0.0416 \\
(0.73)\end{array}$ & $\begin{array}{c}0.3208 * * * \\
(4.82)\end{array}$ \\
\hline Following FSBs & $\begin{array}{l}0.0966 \\
(0.23)\end{array}$ & $\begin{array}{l}-1.0778 * * * \\
(-2.70)\end{array}$ & $\begin{array}{l}0.8988 \\
(1.73)^{*}\end{array}$ & $\begin{array}{l}0.1401 \\
(1.13)\end{array}$ & $\begin{array}{c}0.6163 * * * \\
(4.46)\end{array}$ \\
\hline Following FSBs DownMT2 & $\begin{array}{l}0.1090 \\
(0.12)\end{array}$ & $\begin{array}{l}-1.3323 \\
(-1.40)\end{array}$ & $\begin{array}{l}-0.5989 \\
(-0.39)\end{array}$ & $\begin{array}{l}0.4478 \\
(1.33)\end{array}$ & $\begin{array}{l}-0.1510 \\
(-0.44)\end{array}$ \\
\hline Analyst coverage & $\begin{array}{l}-0.2093 \\
(-1.71)^{*}\end{array}$ & $\begin{array}{l}1.1298^{* * *} \\
(8.34)\end{array}$ & $\begin{array}{l}-0.0013 \\
(-0.01)\end{array}$ & $\begin{array}{c}0.1691 * * * \\
(3.17)\end{array}$ & $\begin{array}{c}0.2801 * * * \\
(4.47)\end{array}$ \\
\hline Market capitalization & $\begin{array}{l}0.7279 * * * \\
(17.92)\end{array}$ & $\begin{array}{l}0.3291^{* * * *} \\
(8.37)\end{array}$ & $\begin{array}{c}0.2977 * * * \\
(8.97)\end{array}$ & $\begin{array}{c}0.0823 * * * \\
(5.00)\end{array}$ & $\begin{array}{l}0.2673 * * * \\
(11.51)\end{array}$ \\
\hline Event-day return & $\begin{array}{l}-0.7783 \\
(-0.50)\end{array}$ & $\begin{array}{l}2.2527 \\
(1.68)^{*}\end{array}$ & $\begin{array}{l}-0.7624 \\
(-0.62)\end{array}$ & $\begin{array}{l}0.0721 \\
(0.15)\end{array}$ & $\begin{array}{c}3.9488^{* * * *} \\
(5.73)\end{array}$ \\
\hline Prior 3-day return & $\begin{array}{l}0.0380 \\
(0.39)\end{array}$ & $\begin{array}{l}0.6513 \\
(0.93)\end{array}$ & $\begin{array}{l}-0.4203 \\
(-0.54)\end{array}$ & $\begin{array}{l}-0.0365 \\
(-0.13)\end{array}$ & $\begin{array}{l}-0.2365 \\
(-0.69)\end{array}$ \\
\hline Benchmark & $\begin{array}{l}46.991 * * * \\
(37.33)\end{array}$ & $\begin{array}{l}1.3695 * * * \\
(2.95)\end{array}$ & $\begin{array}{l}66.008 * * * \\
(24.69)\end{array}$ & $\begin{array}{l}7.6778 * * * \\
(24.99)\end{array}$ & $\begin{array}{l}32.722 * * * \\
(33.89)\end{array}$ \\
\hline
\end{tabular}




\begin{tabular}{lllccc} 
Aggregate volume & 0.0006 & $0.1003 * * *$ & $0.0422^{* * *}$ & 0.0218 & -0.0156 \\
Top 5 analyst & $(0.03)$ & $(4.96)$ & $(2.74)$ & $(1.94)^{*}$ & $(-1.20)$ \\
& $0.4678 * * *$ & $0.1807 * *$ & 0.1373 & -0.0845 & 0.0636 \\
\hline Adjusted $\mathrm{R}^{2}$ & $(3.63)$ & $(1.97)$ & $(1.33)$ & $(-1.61)$ & $(1.09)$ \\
\hline
\end{tabular}

As discussed in Section 2, the literature consistently reports that market responses are evident several days before a recommendation change is released. Accordingly, we now turn to results for each of the three trading days prior to the recommendation release. The results for the prior days will give us a better understanding of whether tipping took place and, if so, what are its consequences. The results for total volume, market share, proportion of buy volume and proportion of sell volume are shown in Table 4, Panels A, B, C and D respectively.

In contrast to the results shown in Panel A of Table 3, the corresponding panel in Table 4 provides strong evidence that, in the days prior to a recommendation release, recommending brokers receive a sizable volume increase for both upgrades and downgrades. On days -1 and -2 , the coefficients are significant at the $1 \%$ level; on day -3 , the coefficients are significant at the 5\% level. Results for the other four categories are, in contrast, overwhelmingly negative or not significant. Taken together, these results offer strong support for the reward hypothesis and the economic benefits accruing to the recommending brokers and no evidence to support a finding of free riding. ${ }^{15}$ Our findings are also consistent with the presence of tipping as suggested by Irvine, Lipson and Puckett (2007) whereby brokers release analyst reports to selected clients earlier than to other clients. The results in Panel B provide evidence that recommending brokers benefit from increased market share on each of the three days prior to day 0 for both upgrades and downgrades. For upgrades, there is a similar pattern for brokers who follow the stock and make a recommendation change within the window but not on day 0 , but for downgrades the pattern is only weakly evident. Almost all results for the other three broker categories are not positively significant. Hence, these results also overwhelmingly support the reward hypothesis.

The results in Panel C suggest that recommending brokers and brokers who follow the stock and made a recommendation change within the window but not on day 0 experience an

\footnotetext{
${ }^{14}$ To save space, we report only the coefficients on the main variables of interest.

${ }^{15}$ As in Table 3, a stacked regression approach is also used. The results for day -1 again are relatively similar to those reported in Table 4, particularly for upgrades. However, for day -2 and day -3 , the results for the recommending broker are weaker but the results for the other brokers are more significantly negative.
} 
increase in buy orders in the case of recommendation upgrades in the three days preceding a recommendation upgrade. Hence, the positive effect observed on the day of the release (see Panel $\mathrm{C}$ of Table 3) begins up to three days before the release. In the case of sell orders (Panel D), the only result significant at the 5\% level is an increase in the proportion of sell orders transacted by recommending brokers on the day before a downgrade is released. This result is similar to that reported by $\mathrm{J} \& \mathrm{~L}$.

\section{Table 4 : Regression Results from Day -3 to Day -1 Prior to Recommendation}

Broker categories are:

(i) the broker whose recommendation was changed on day 0 (the 'recommending broker');

(ii) a broker who follows the stock and has released a recommendation change within the event window but not on day 0;

(iii) a broker who follows the stock but has not released a recommendation change within the event window;

(iv) a broker who is a full-service broker but does not follow the stock and

(v) a broker who is a discount broker.

The coefficients of the recommendation upgrade and downgrade for each category from the regression equation with the t-statistics are disclosed for different dependent variables in Panels A to D. Superscripts ***,**, * represent the $1 \%, 5 \%$ and $10 \%$ significance levels (two-tail test) respectively.

\begin{tabular}{|c|c|c|c|c|c|}
\hline \multicolumn{6}{|l|}{ Panel A : Total Volume } \\
\hline \multicolumn{6}{|l|}{ Day -1} \\
\hline & $\begin{array}{l}\text { Broker } \\
\text { category } \\
\text { (i) }\end{array}$ & $\begin{array}{c}\text { Broker } \\
\text { category } \\
\text { (ii) }\end{array}$ & $\begin{array}{c}\text { Broker } \\
\text { category } \\
\text { (iii) }\end{array}$ & $\begin{array}{c}\text { Broker } \\
\text { category } \\
\text { (iv) }\end{array}$ & $\begin{array}{c}\text { Broker } \\
\text { category } \\
\text { (v) }\end{array}$ \\
\hline Recommendation upgrade & $\begin{array}{l}0.9063^{* * * *} \\
(3.58)\end{array}$ & $\begin{array}{l}0.1165 \\
(0.86)\end{array}$ & $\begin{array}{l}-0.0914 \\
(-0.77)\end{array}$ & $\begin{array}{l}-0.1137 \\
(-1.24)\end{array}$ & $\begin{array}{l}-0.1088 \\
(-1.28)\end{array}$ \\
\hline Recommendation downgrade & $\begin{array}{l}0.7253^{* * *} \\
(2.86)\end{array}$ & $\begin{array}{l}0.1076 \\
(0.81)\end{array}$ & $\begin{array}{l}-0.1438 \\
(-1.21)\end{array}$ & $\begin{array}{l}-0.1070 \\
(-1.19)\end{array}$ & $\begin{array}{l}-0.1021 \\
(-1.21)\end{array}$ \\
\hline \multicolumn{6}{|l|}{ Day -2} \\
\hline & $\begin{array}{l}\text { Broker } \\
\text { category } \\
\text { (i) }\end{array}$ & $\begin{array}{c}\text { Broker } \\
\text { category } \\
\text { (ii) }\end{array}$ & $\begin{array}{c}\text { Broker } \\
\text { category } \\
\text { (iii) }\end{array}$ & $\begin{array}{c}\text { Broker } \\
\text { category } \\
\text { (iv) }\end{array}$ & $\begin{array}{c}\text { Broker } \\
\text { category } \\
\text { (v) }\end{array}$ \\
\hline Recommendation upgrade & $\begin{array}{l}0.7104^{* * *} \\
(2.93)\end{array}$ & $\begin{array}{l}0.0923 \\
(0.66)\end{array}$ & $\begin{array}{l}-0.2129 * * \\
(-1.96)\end{array}$ & $\begin{array}{l}-0.0031 \\
(-0.03)\end{array}$ & $\begin{array}{l}-0.1299 \\
(-1.52)\end{array}$ \\
\hline Recommendation downgrade & $\begin{array}{l}0.6933 * * * \\
(2.88)\end{array}$ & $\begin{array}{l}-0.0209 \\
(-0.15)\end{array}$ & $\begin{array}{l}-0.2738^{* *} \\
(-2.50)\end{array}$ & $\begin{array}{l}-0.0416 \\
(-0.41)\end{array}$ & $\begin{array}{l}-0.1721 * * \\
(-1.99)\end{array}$ \\
\hline
\end{tabular}

Day -3 


\begin{tabular}{|c|c|c|c|c|c|}
\hline & $\begin{array}{c}\text { Broker } \\
\text { category } \\
\text { (i) }\end{array}$ & $\begin{array}{c}\text { Broker } \\
\text { category } \\
\text { (ii) }\end{array}$ & $\begin{array}{c}\text { Broker } \\
\text { category } \\
\text { (iii) }\end{array}$ & $\begin{array}{c}\text { Broker } \\
\text { category } \\
\text { (iv) }\end{array}$ & $\begin{array}{c}\text { Broker } \\
\text { category } \\
\text { (v) }\end{array}$ \\
\hline \multirow[t]{2}{*}{ Recommendation upgrade } & $0.5237 * *$ & $0.3050 *$ & 0.0156 & 0.0078 & -0.0762 \\
\hline & $(2.11)$ & (1.94) & $(0.12)$ & $(0.07)$ & $(-0.76)$ \\
\hline \multirow{2}{*}{ Recommendation downgrade } & $0.5173 * *$ & 0.1624 & -0.0345 & -0.0392 & -0.0594 \\
\hline & $(2.09)$ & $(1.04)$ & $(-0.25)$ & $(-0.35)$ & $(-0.60)$ \\
\hline
\end{tabular}

Table 4 : Regression Results from Day -3 to Day -1 Prior to Recommendation (Contd.)

\begin{tabular}{|c|c|c|c|c|c|}
\hline \multicolumn{6}{|l|}{ Panel B: Market Share } \\
\hline \multicolumn{6}{|l|}{ Day -1 } \\
\hline & $\begin{array}{c}\text { Broker } \\
\text { category } \\
\text { (i) }\end{array}$ & $\begin{array}{c}\text { Broker } \\
\text { category } \\
\text { (ii) }\end{array}$ & $\begin{array}{c}\text { Broker } \\
\text { category } \\
\text { (iii) }\end{array}$ & $\begin{array}{c}\text { Broker } \\
\text { category } \\
\text { (iv) }\end{array}$ & $\begin{array}{c}\text { Broker } \\
\text { category } \\
(\mathrm{v})\end{array}$ \\
\hline Recommendation upgrade & $\begin{array}{l}0.7444 * * * \\
(3.73)\end{array}$ & $\begin{array}{l}0.3602 * * \\
(2.17)\end{array}$ & $\begin{array}{l}-0.1761 \\
(-1.24)\end{array}$ & $\begin{array}{l}0.0025 \\
(0.03)\end{array}$ & $\begin{array}{l}-0.0147 \\
(-0.17)\end{array}$ \\
\hline Recommendation downgrade & $\begin{array}{l}0.5960^{* * * *} \\
(2.99)\end{array}$ & $\begin{array}{l}0.2928^{*} \\
(1.77)\end{array}$ & $\begin{array}{l}-0.1871 \\
(-1.31)\end{array}$ & $\begin{array}{l}0.0166 \\
(0.17)\end{array}$ & $\begin{array}{l}-0.0026 \\
(-0.03)\end{array}$ \\
\hline \multicolumn{6}{|l|}{ Day -2 } \\
\hline & $\begin{array}{c}\text { Broker } \\
\text { category } \\
\text { (i) }\end{array}$ & $\begin{array}{c}\text { Broker } \\
\text { category } \\
\text { (ii) }\end{array}$ & $\begin{array}{c}\text { Broker } \\
\text { category } \\
\text { (iii) }\end{array}$ & $\begin{array}{c}\text { Broker } \\
\text { category } \\
\text { (iv) }\end{array}$ & $\begin{array}{c}\text { Broker } \\
\text { category } \\
\text { (v) }\end{array}$ \\
\hline Recommendation upgrade & $\begin{array}{l}0.5636^{* * *} \\
(2.89)\end{array}$ & $\begin{array}{l}0.3269^{* *} \\
(1.98)\end{array}$ & $\begin{array}{l}-0.3210^{* *} \\
(-2.23)\end{array}$ & $\begin{array}{l}0.1293 \\
(1.32)\end{array}$ & $\begin{array}{l}-0.0483 \\
(-0.56)\end{array}$ \\
\hline Recommendation downgrade & $\begin{array}{l}0.5224 * * * \\
(2.69)\end{array}$ & $\begin{array}{l}0.1801 \\
(1.08)\end{array}$ & $\begin{array}{l}-0.3560 * * \\
(-2.47)\end{array}$ & $\begin{array}{l}0.0758 \\
(0.77)\end{array}$ & $\begin{array}{l}-0.1117 \\
(-1.29)\end{array}$ \\
\hline \multicolumn{6}{|l|}{ Day -3} \\
\hline 7 & $\begin{array}{c}\text { Broker } \\
\text { category } \\
\text { (i) }\end{array}$ & $\begin{array}{c}\text { Broker } \\
\text { category } \\
\text { (ii) }\end{array}$ & $\begin{array}{c}\text { Broker } \\
\text { category } \\
\text { (iii) }\end{array}$ & $\begin{array}{c}\text { Broker } \\
\text { category } \\
\text { (iv) }\end{array}$ & $\begin{array}{c}\text { Broker } \\
\text { category } \\
\text { (v) }\end{array}$ \\
\hline Recommendation upgrade & $\begin{array}{l}0.4207 * * \\
(2.10)\end{array}$ & $\begin{array}{l}0.5167 * * * \\
(2.89)\end{array}$ & $\begin{array}{l}-0.1505 \\
(-1.02)\end{array}$ & $\begin{array}{l}0.0960 \\
(0.88)\end{array}$ & $\begin{array}{l}0.0018 \\
(0.02)\end{array}$ \\
\hline Recommendation downgrade & $\begin{array}{l}0.4089 * * \\
(2.05)\end{array}$ & $\begin{array}{l}0.3481 * \\
(1.94)\end{array}$ & $\begin{array}{l}-0.1602 \\
(-1.09)\end{array}$ & $\begin{array}{l}0.0477 \\
(0.44)\end{array}$ & $\begin{array}{l}0.0294 \\
(0.32)\end{array}$ \\
\hline
\end{tabular}


Table 4 : Regression Results from Day -3 to Day -1 Prior to Recommendation (Contd.)

\begin{tabular}{|c|c|c|c|c|c|}
\hline \multicolumn{6}{|c|}{ Panel C : Proportional Buy Volume } \\
\hline \multicolumn{6}{|l|}{ Day -1} \\
\hline & $\begin{array}{l}\text { Broker } \\
\text { category } \\
\text { (i) }\end{array}$ & $\begin{array}{l}\text { Broker } \\
\text { category } \\
\text { (ii) }\end{array}$ & $\begin{array}{l}\text { Broker } \\
\text { category } \\
\text { (iii) }\end{array}$ & $\begin{array}{l}\text { Broker } \\
\text { category } \\
\text { (iv) }\end{array}$ & $\begin{array}{l}\text { Broker } \\
\text { category } \\
\text { (v) }\end{array}$ \\
\hline Recommendation upgrade & $\begin{array}{l}0.3827 * * * \\
(4.08)\end{array}$ & $\begin{array}{l}0.1859^{* *} \\
(2.54)\end{array}$ & $\begin{array}{l}-0.0005 \\
(-0.01)\end{array}$ & $\begin{array}{l}-0.0036 \\
(-0.08)\end{array}$ & $\begin{array}{l}0.0370 \\
(0.77)\end{array}$ \\
\hline \multicolumn{6}{|l|}{ Day -2 } \\
\hline & $\begin{array}{l}\text { Broker } \\
\text { category } \\
\text { (i) }\end{array}$ & $\begin{array}{l}\text { Broker } \\
\text { category } \\
\text { (ii) }\end{array}$ & $\begin{array}{l}\text { Broker } \\
\text { category } \\
\text { (iii) }\end{array}$ & $\begin{array}{l}\text { Broker } \\
\text { category } \\
\text { (iv) }\end{array}$ & $\begin{array}{l}\text { Broker } \\
\text { category } \\
\text { (v) }\end{array}$ \\
\hline Recommendation upgrade & $\begin{array}{l}0.3827 * * * \\
(4.08)\end{array}$ & $\begin{array}{l}0.1859^{* *} \\
(2.54)\end{array}$ & $\begin{array}{l}-0.0005 \\
(-0.01)\end{array}$ & $\begin{array}{l}-0.0036 \\
(-0.08)\end{array}$ & $\begin{array}{l}0.0370 \\
(0.77)\end{array}$ \\
\hline \multicolumn{6}{|l|}{ Day -3} \\
\hline & $\begin{array}{l}\text { Broker } \\
\text { category } \\
\text { (i) }\end{array}$ & $\begin{array}{l}\text { Broker } \\
\text { category } \\
\text { (ii) }\end{array}$ & $\begin{array}{l}\text { Broker } \\
\text { category } \\
\text { (iii) }\end{array}$ & $\begin{array}{l}\text { Broker } \\
\text { category } \\
\text { (iv) }\end{array}$ & $\begin{array}{l}\text { Broker } \\
\text { category } \\
\text { (v) }\end{array}$ \\
\hline Recommendation upgrade & $\begin{array}{l}0.2205^{* *} \\
(2.37)\end{array}$ & $\begin{array}{l}0.1648 * * \\
(2.19)\end{array}$ & $\begin{array}{l}-0.0071 \\
(-0.11)\end{array}$ & $\begin{array}{l}0.0831 * \\
(1.82)\end{array}$ & $\begin{array}{l}0.0569 \\
(1.14)\end{array}$ \\
\hline
\end{tabular}

\begin{tabular}{|c|c|c|c|c|c|}
\hline \multicolumn{6}{|c|}{ Panel D : Proportional Sell Volume } \\
\hline Day -1 & & & & & \\
\hline & $\begin{array}{c}\text { Broker } \\
\text { category } \\
\text { (i) }\end{array}$ & $\begin{array}{c}\text { Broker } \\
\text { category } \\
\text { (ii) }\end{array}$ & $\begin{array}{c}\text { Broker } \\
\text { category } \\
\text { (iii) }\end{array}$ & $\begin{array}{c}\text { Broker } \\
\text { category } \\
\text { (iv) }\end{array}$ & $\begin{array}{c}\text { Broker } \\
\text { category } \\
\text { (v) }\end{array}$ \\
\hline Recommendation downgrade & $\begin{array}{l}0.2062 * * \\
(2.24)\end{array}$ & $\begin{array}{l}0.0138 \\
(0.19)\end{array}$ & $\begin{array}{l}-0.0250 \\
(-0.38)\end{array}$ & $\begin{array}{l}-0.0167 \\
(-0.38)\end{array}$ & $\begin{array}{l}0.0688 \\
(1.31)\end{array}$ \\
\hline \multicolumn{6}{|l|}{ Day -2 } \\
\hline & $\begin{array}{c}\text { Broker } \\
\text { category } \\
\text { (i) }\end{array}$ & $\begin{array}{c}\text { Broker } \\
\text { category } \\
\text { (ii) }\end{array}$ & $\begin{array}{c}\text { Broker } \\
\text { category } \\
\text { (iii) }\end{array}$ & $\begin{array}{c}\text { Broker } \\
\text { category } \\
\text { (iv) }\end{array}$ & $\begin{array}{c}\text { Broker } \\
\text { category } \\
\text { (v) }\end{array}$ \\
\hline Recommendation downgrade & $\begin{array}{l}0.1113 \\
(1.21)\end{array}$ & $\begin{array}{l}-0.0609 \\
(-0.83)\end{array}$ & $\begin{array}{l}-0.0471 \\
(-0.70)\end{array}$ & $\begin{array}{l}-0.0658 \\
(-1.45)\end{array}$ & $\begin{array}{l}-0.0377 \\
(-0.70)\end{array}$ \\
\hline
\end{tabular}

\section{Day $-\mathbf{3}$}




\begin{tabular}{lccccc}
\hline & $\begin{array}{c}\text { Broker } \\
\text { category }\end{array}$ & $\begin{array}{c}\text { Broker } \\
\text { category }\end{array}$ & $\begin{array}{c}\text { Broker } \\
\text { category }\end{array}$ & $\begin{array}{c}\text { Broker } \\
\text { category }\end{array}$ & $\begin{array}{c}\text { Broker } \\
\text { category } \\
\text { (i) }\end{array}$ \\
& (ii) & (iii) & (iv) & (v) \\
\hline Recommendation downgrade & 0.1186 & -0.0920 & -0.0341 & -0.0210 & 0.0980 \\
& $(1.27)$ & $(-1.24)$ & $(-0.52)$ & $(-0.46)$ & $(1.78)^{*}$ \\
\hline
\end{tabular}

\section{Conclusion}

Juergens and Lindsey (2009) study the NASDAQ market, which is predominantly a dealerdriven system with market makers. They find that brokers who make recommendations are rewarded with increased volume of trades in the short term (i.e. a 'reward' effect). However, it is unclear whether this finding will hold in other international markets with alternative trading systems and whether there is a free-riding effect. Our goal is to perform analysis which resolves this tension.

Specifically, we use an Australian sample as a representative example of a central limit order system. Our main finding is that there is strong evidence to support the reward hypothesis. In the case of discount brokers, there is no evidence consistent with free riding. There is, however, strong evidence that recommending brokers benefit from an increase in trading volume in the three-day period before the release of a recommendation change. This finding is consistent with some clients receiving early notice (tips) from brokers on forthcoming recommendation changes and these clients then rewarding such brokers with an immediate increase in trading volume. As to the reasons why clients prefer to channel their trades through full-service recommending brokers despite the commission advantage of trading through discount brokers, we conjecture that this is due to the full suite of services offered by the full-service brokers. This includes the provision of liquidity, better bid-ask spread, lower market impact and opportunities to gain from tips. Therefore, on an overall basis, it is still more economically beneficial to trade through a full-service broker.

Like J\&L, we find a significant pattern among sell orders on the day preceding downgrades. However, unlike J\&L, we find that volume increases also occur in buy orders in the three days preceding upgrades. In this respect, our findings for a central limit order market suggest that the results and conclusions reached by $\mathrm{J} \& \mathrm{~L}$ can be generalized beyond the dealer-driven market. This may suggest that the results and findings of $J \& L$ are applicable to the spectrum of trading systems currently available in the stock exchanges.

\section{References}


Agrawal, A., and M.A. Chen, 2008, Do analysts conflicts matter? Evidence from stock recommendations, Journal of Law and Economics 51, 503-537.

Anderson, A., and J.V. Martinez, 2010, Broker trading ahead of stock recommendations, Working paper 78 (Institute for Financial Research, Sweden).

Australian Investors Association, 2003, Discount Brokers Survey. Available at http://svc253.wic012v.serverweb.com/downloads/MediaReleases/GA10Media031203c.pdf, accessed September 28, 2012.

Christophe, S., M. Ferri, and J. Hsieh, 2010, Informed trading before analyst downgrades: Evidence from short selling, Journal of Financial Economics 95, 85-106.

Clayton, M.J, B.N. Jorgensen, and K.A. Kavajecz, 2006, On the presence and marketstructure of exchanges around the world, Journal of Financial Markets 9, 27-48.

Francis, J., and L. Soffer, 1997, The relative informativeness of analysts' stock recommendations and earnings forecast revisions, Journal of Accounting Research 35, $193-211$.

Goldstein, M.A., P. Irvine, E. Kandel, and Z. Wiener, 2009, Brokerage commissions and institutional trading patterns, Review of Financial Studies 22, 5175-5212.

Harris, R., and M. Ho, 1998, Market reactions to messages from brokerage ratings systems, Financial Analysts Journal 54, 49-57.

Howe J., E. Unlu, and X. Yan, 2009, The predictive content of aggregate analyst recommendations, Journal of Accounting Research 47, 799-821.

Irvine, P.J., 2004. Analysts' forecasts and brokerage-firm trading, Accounting Review 79, $125-149$.

Irvine, P.J., and M. Lipson, and A. Puckett, 2007, Tipping, Review of Financial Studies 20, $741-768$.

Jain, P., 2003, Institutional design and liquidity at stock exchanges around the world, Working paper (University of Memphis).

Jegadeesh, N., J. Kim, S.D. Ritchie, C.M.C. Lee, 2004. Analyzing the analysts: When do recommendations add value?, Journal of Finance 59, 1083-1124. 
Juergens, J.L., and L. Lindsey, 2009, Getting out early: An analysis of market making activity at the recommending analyst's firm, Journal of Finance 64, 2327-2359.

Krische, S.D., and C.M.C. Lee, 2000, The information content of analyst stock recommendations, Working paper (Cornell University).

Leone, A.J., and S.J. Wu, 2002, What does it take to become a superstar? Evidence from Institutional Investor rankings of financial analysts, Working paper (University of Rochester).

Lepone, A., H. Leung, and J.G. Li, 2012, Unequal access to analyst research, Australian Journal of Management 38, 253-277.

Mikhail, M.B., B.R. Walther, and R.H. Willis, 2007, When security analysts talk, who listens?, Accounting Review 82, 1227-1253.

Stickel, S., 1995, The anatomy of the performance of buy and sell recommendations, Financial Analysts Journal 51, 25-39.

Tolhurst, C., 2012, Mix up your brokers, keep costs down, Australian Financial Review, September 25.

Womack, K. 1996, Do brokerage analysts' recommendations have investment value?, Journal of Finance 51, 137-167.

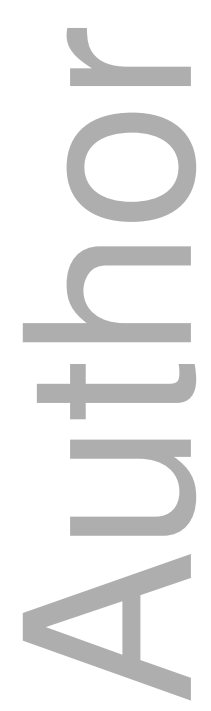




\section{University Library}

\section{- M M I N E R VA A gateway to Melbourne's research publications}

Minerva Access is the Institutional Repository of The University of Melbourne

\section{Author/s:}

Chan, HWH;Faff, RW;Ho, YK;Brown, R

Title:

Do brokers' recommendation changes generate brokerage? Evidence from a central limit order market

\section{Date:}

2019-03-01

\section{Citation:}

Chan, H. W. H., Faff, R. W., Ho, Y. K. \& Brown, R. (2019). Do brokers' recommendation changes generate brokerage? Evidence from a central limit order market. Accounting and Finance, 59 (1), pp.115-142. https://doi.org/10.1111/acfi.12255.

Persistent Link:

http://hdl.handle.net/11343/292240 